\title{
Kohezyonsuz Zeminlerin Tane Dağılım ve Şekil Özelliklerinin Aktif Göçme Yüzeyi Geometrisine Etkileri
}

\author{
Çağdaş ARDA ${ }^{1}$ \\ Özer ÇiNíCiOĞLLU
}

\section{ÖZ}

İstinat duvarlarının aktif göçme durumuna ulaşması sonucunda oluşan kayma yüzeylerinin geometrileri, granüler dolguların genleşme davranışından etkilenmektedir. Literatürdeki gerilme-genleşme denklemleri bağıl birim hacim ağırlığın ve gerilme durumunun zeminin genleşme davranışına etkilerini ortaya koymaktadır. Fakat bu değişkenlerin göçme anında oluşacak kayma bandı geometrisine etkilerini model deneyleri ile araştıran mevcut çalışmalar düşük gerilmeler altında ve zeminlerin makro-mekanik özellikleri dikkate alınmadan gerçekleştirilmiştir. Bu nedenle, bu çalışmada kullanılmak üzere aktif yönde yanal olarak hareket edebilen ve düşey yönde sürşarj uygulayabilen küçük ölçekli bir $1 \mathrm{~g}$ fiziksel istinat duvarı modeli oluşturulmuştur. Fiziksel model deney düzeneği kullanılarak farklı tane şekli ve boyutlarına sahip üç farklı granüler dolgu malzemesi ile çeşitli sıkılık-gerilme tertiplerinde deneyler yapılmıştır. Yapılan model deneylerinin görüntüleri parçacık görüntülü hız ölçümü (PGHÖ) yöntemi ile çözümlenmiş ve kayma yüzeyi geometrileri elde edilmiştir. Böylece tane boyutu, şekli ve sürşarj yükünün göçme anındaki kayma yüzeyi geometrilerine etkileri araştırılmıştır.

Anahtar Kelimeler: Genleşme açısı, PGHÖ, fiziksel model, göçme yüzeyi, istinat duvarı.

\section{ABSTRACT \\ The Influences of Micro-Mechanical Properties of Cohesionless Soils on Active Failure Surface Geometries}

The geometry of active failure surface is influenced by the dilatant properties of granular backfills. Stress-dilatancy functions available in the literature suggest that dilatant behavior is dependent on relative density and the state of stress. However, because physical modelling

\footnotetext{
Not: Bu yazı

- Yayın Kurulu'na 22 Şubat 2018 günü ulaşmıştır. 29 Ağustos 2018 günü yayımlanmak üzere kabul edilmiştir.

- 30 Kasım 2019 gününe kadar tartışmaya açıktır.

- https://dx.doi.org/10.18400/tekderg.397658

1 Boğaziçi Üniversitesi, İnşaat Mühendisliği Bölümü, İstanbul - cagdas.arda@boun.edu.tr https://orcid.org/0000-0001-9843-0532

2 Boğaziçi Üniversitesi, İnşaat Mühendisliği Bölümü, İstanbul - ozer.cinicioglu@boun.edu.tr https://orcid.org/0000-0001-9334-6956
} 
studies investigating the influence of these variables were conducted under small stresses and without considering macro-mechanical properties of soils, a new small-scale $1 \mathrm{~g}$ physical retaining wall model that can translate to active state and apply vertical surcharge is designed. Using this setup, physical model tests using three different granular backfill materials were conducted under various density and stress state combinations. Images from these tests were analyzed using particle image velocimetry method (PIV) and failure surface geometries were defined. Thus, it was possible to study the influences of mean grain size, particle shape, and surcharge on failure surface geometries.

Keywords: Dilatancy angle, PIV, physical model, failure surface, retaining wall.

\section{GİRiş}

İstinat duvarlarının yatay hareketleri duvar arkasında yer alan granüler dolgunun hacimsel ve kayma şekil değiştirmelerine sebep olur. Söz konusu şekil değiştirmeler, göçme anına kadar devam eden duvar hareketleri süresince "kayma bandı" olarak adlandırılan bölgede yoğunlaşır ve kayma bandı ile duvar arasında kalan zemin kayma kaması olarak tanımlanır $[1,2]$. Kayma bandının yatay ile yaptığı açı $(\alpha)$ aktif veya pasif göçme şartlarında istinat yapısı üzerine etkiyecek basıncın hesaplanabilmesi için gereklidir. Rankine (1856) yayımladığı makalesinde Coulomb'un kayma kaması hipotezinden (1776) yola çıkarak bu mekanizmanın granüler zeminlerde zemin tanelerinin karşılıklı sürtünmesi sonucu meydana geldiğini öne sürmüş, doğrusal olduğunu varsaydığı göçme yüzeyi geometrisinin MohrCoulomb kayma hipotezine bağlı olarak,

$\alpha=45^{\circ}+\phi^{\prime} / 2$

bağıntısı ile hesaplanabileceğini belirtmiştir. Eşitlik 1'de, $\phi^{\prime}$ zeminin içsel sürtünme açısıdır. $\mathrm{Bu}$ bağıntı inşaat mühendislerince bilinen bir bağıntı olduğu için uygulamada sıklıkla kullanılmaktadır.

Sonraki yıllarda yapılan araştırmalar, göçme yüzeyi geometrisinin duvar - zemin arasındaki sürtünmeden ve zeminin genleşme açısından etkilendiğini göstermiştir. Tsagareli (1965) gerçekleştirdiği deneyler ile kayma yüzeyinin şeklini sürtünme açısına bağlı üssel bir fonksiyon ile tanımlamıştır [3].

$\alpha=C\left(3.6 \phi^{\prime}+0.5\right)^{x / C}$

Eşitlik 2'de $\phi^{\prime}$ radyan cinsinden içsel sürtünme açısını, $x$ kayma bandı üzerindeki bir noktanın istinat duvarına olan yatay mesafesini ifade etmektedir. $C$ ise duvar uzunluğuna bağlı bir katsayıdır. Fakat bu çalışmada genleşmenin etkisi dikkate alınmamış, kayma yüzeyinin parabolik biçiminin duvar sürtünmesi etkisi ile oluştuğu ifade edilmiştir.

1980'li yıllarda yapılan iki çalışma en büyük genleşme açısının $\left(\psi_{p}\right)$ göçme yüzeyi geometrisine ve yatay toprak basıncına etkilerini ilk defa tanımlamıştır. Bunlardan ilk olarak Vardoulakis (1980), düzlem şekil değiştirme şartlarında yaptığı deneylerde yük altında numunede oluşan kayma şekil değiştirmelerinin oluşumunda genleşme davranışının da etkin olduğunu Mohr-Coulomb yaklaşımından türettiği analitik bağıntılar ile ifade etmiştir [4]. 
Daha sonra gerçekleştirdiği fiziksel model deneyleri ile ölçtüğü $\alpha$ açılarının denklem ile örtüştügünü göstermiştir.

$\alpha=45^{0}+\frac{1}{4}\left(\phi_{p}^{\prime}+\psi_{p}^{\prime}\right)$

Fakat Eşitlik 3 doğrusal olup, parabolik bir geometriye sahip gerçek göçme yüzeyi geometrisi ile örtüşmemektedir. Ardından Bang (1985) aktif yatay toprak basıncının oluşumuna duvar eğiminin etkisini araştıran çalışmasında sunduğu analitik formülde duvar hareketinin yatay toprak basıncına etkisini $\psi_{p}$ değeri ile göstermiştir [5].

Diğer birçok araştırmacı ise genleşme etkisini duvar hareketi sırasında oluşan ve deneysel olarak ölçümü çok güç olan kemerlenme davranışına dayandırmaktadır $[6,7,8,9,10]$. Kemerlenme ile genleşme mekanizmalarının her ikisi de kum tanelerinin birbirlerine kenetlenmeleri sonucunda ortaya çıkmaktadır. Tanelerin kenetlenmesinin sonucu olan iki mekanizmadan kemerlenmenin ölçümü çok zor olduğu için genleşmeyi kayma yüzeylerinin geometrileri ile ilişkilendirmek pratik açıdan daha anlamlıdır. M. Kowalska (2014), $\psi / \phi^{\prime}$ oranının istinat duvarı arkasındaki kayma bandı geometrisine etkisini belirlemek için bir istinat duvarını sonlu elemanlar yöntemi ile modelleyerek sayısal analizler yapmıştır [11]. Çalışma sonrasında artan sürşarjın genleşme değerini sınırladığını ve $\psi / \phi^{\prime}$ oranının azalmasına neden olduğunu ortaya koymuştur. Fakat, sürşarj etkisiyle istinat duvarının arkasında oluşan gerilme dağılımı fiziksel olarak modellenemediğinden, genleşmenin kayma bandı geometrisine etkisi görselleştirilememiştir.

Öte yandan granüler zeminlerin sıkılık ve gerilme değişimi gibi fiziksel özellikleri yanında tane mineralojisi, şekli, boyutları gibi mikro-mekanik özelliklerinin de zeminin mukavemetine etkileri Oda (1972), Holubec ve Appolonia (1973), Frossard (1979), Jensen v.d. (2001), Santamarina ve Cho (2004) gibi araştırmacılar tarafından incelenmiştir [12, 13, 14, 15, 16]. Amirpour ve diğ. (2017), çok sayıda farklı tane çapı dağılımına sahip, köşeli ya da yuvarlak gibi değişken tane şekillerindeki kumlar üzerinde yaptıkları konsolidasyonlu ve drenajlı üç eksenli deneylerde ortalama tane çapı $\left(\mathrm{D}_{50}\right)$ değerinin tane şekline göre gerilmegenleşme davranışını etkilediğini tespit etmiş, zeminin $\mathrm{D}_{50}$ değeri yükseldikçe genleşme açısının azaldığını ortaya koymuştur [17]. Bunula beraber, daha köşeli tane şekline sahip kumlarda genleşme davranışının etkisi daha yüksek olmaktadır [13].

Yapılan tüm bu araştırmalar dikkate alındığında, zeminlerin göçme yüzeyi geometrilerinin analitik yolla tespit edilmesinde yüksek gerilmelerin (sürşarj etkisi) ile zeminlerin dane dağılımı ve şekil özelliklerinin birleşik etkilerinin henüz dikkate alınmadığı tespit edilmiştir. Dolayısıyla, bu çalışmada tane şekli ya da granülometrisi birbirinden farklı olan üç farklı granüler zemin üzerinde aktif yönde hareket eden istinat duvarı model deneyleri yapılmıştır. Deneylerde model düzeneğinin kemerlenme etkisini önleyecek genişlikte tutulmasına özen gösterilmiştir. Her test için parçacık görüntülü hız ölçümü (PGHÖ) metodu kullanılarak değişken göreceli sıkılık ve sürşarj yükleri altında zeminlerin göçme anındaki kayma düzlemleri gözlemlenmiştir. Her deney için kumların düzlem gerilme genleşme açısı ve içsel sürtünme açısı gibi mukavemet parametreleri Bolton (1986) tarafından önerilen ve literatürde geniş kabul gören gerilme-genleşme bağıntısı kullanılarak hesaplanmıştır [18]. Böylece, deneysel olarak elde edilen kayma düzlemi geometrileri ile gerilme-genleşme bağıntısı kullanılarak hesaplanmış genleşme özellikleri arasında bağlantı kurmak mümkün olmuştur. Elde edilen sonuçlar tartışılmış ve aktif göçme yüzeylerinin geometrilerini etkileyen mikro- 
mekanik özellikler sunulmuştur. Bu sonuçlardan yola çıkarak oluşan göçme yüzeyi geometrisi ile genleşme açısı arasındaki ilişkinin önceki araştırmalar ile önerilen analitik bağıntılar ile uygunluğu araştırılmış, tane boyutu ve şeklinin yüksek gerilmeler altında kayma düzlemi oluşumuna etkileri incelenmiştir.

\section{KUMLARDA SÜRTÜNME VE GENLEŞME MEKANIZMALARI}

Kohezyonsuz sıkı zeminlerin gerilme - şekil değiştirme ilişkisinde tanelerin kilitlenme etkisi ile maksimum içsel sürtünme açısı kritik durum sürtünme açısının üstüne yükselmektedir. $\mathrm{Bu}$ da hacimsel genleşme davranışının zeminlerin mukavemetine etkisini ortaya koymaktadır. Granüler zeminlerde genleşmenin fiziksel varlığı ilk kez Reynolds (1885) tarafından tespit edilmiştir [19]. Fakat genleşmenin mekanik olarak tanımlanması 20. yüzyılın ortasını bulmuştur. Bu teorilerden en öne çıkanlar testere diş modeli (Taylor 1948) ile iş yayılma teorisine dayalı Rowe (1962 ve 1969) ile Jong (1976) tarafından önerilen gerilme-genleşme ilişkileridir [20, 21, 22, 23]. Özellikle testere diş modeli taneler arası kilitlenme mekanizmasının sürtünme direncine etkisine teorik bir açıklama getirmektedir. Fakat testere diş modeli ile hesaplanan içsel sürtünme açıları deneysel sonuçlar ile uyuşmamaktadır. Bunu tespit eden Bishop (1971) deneysel bir çalışma ile genleşmenin içsel sürtünmeyi ne kadar etkilediğini deneye dayalı ' $r$ ' katsayısı ile tanımlamıştır (Eşitlik 4) [24].

$r=\frac{\phi_{p}^{\prime}-\phi_{c}^{\prime}}{\psi_{p}}$

Burada $\phi^{\prime}{ }_{c}$ kritik durum kayma açısıdır. İçsel sürtünme ve genleşme açıları için en büyük değerlerin (sırasıyla $\phi_{p}^{\prime}$ ve $\psi_{p}$ ) kullanılmasının sebebi $\psi$ değerinin kayma süresince değişmesi ve zeminlerin davranışlarının bu değerlerle ilişkili olmalarıdır. Bilindiği üzere genleşme açısı Eşitlik 5'te gösterildiği gibi hesaplanır.

$\tan \psi=-\frac{d \varepsilon_{v}}{d \gamma}$

Burada $d \varepsilon_{v}$ birim hacimsel değişim, $d \gamma$ birim şekil değiştirmedir. Zeminin kayma davranış1 süresince $-d \varepsilon_{v} / d \gamma$ oranı değişeceği için $\psi$ değeri de değişecektir. Eşitlik 5 ile hesaplanan en yüksek $\psi$ değeri $\psi_{p}$ ile gösterilmektedir ve bu değer Şekil 1'de gösterildiği gibi en yüksek kayma gerilmesinin (q) ölçüldüğü aşamaya karşılık gelmektedir.

Bolton (1986) literatürde mevcut üç eksenli deney verilerini derleyerek $\psi_{p}$ değerinin hesaplanabilmesi için ampirik bir bağıntı geliştirmiştir [18]:

$\psi_{p}=\frac{A_{\psi}}{r}\left[I_{D}\left(Q-\ln \frac{100 p_{f}^{\prime}}{p_{a}}\right)-R\right]=\left(A_{\psi} \times I_{R}\right) / r$

Eşitlik 6'da $p_{f}^{\prime}$ göçme anındaki ortalama efektif gerilme değerini, $p_{a}$ atmosferik basıncı ifade etmektedir. Üç eksenli deneylerdeki eksenel simetrik durum için $p_{f}^{\prime}=\left(\sigma_{1}^{\prime}+2 \sigma_{3}^{\prime}\right) / 3$, üç boyutlu fiziksel model deneylerindeki düzlem gerilme koşulu için ise $p_{f}{ }_{f}=$ $\left(\sigma_{1}^{\prime}+K_{o} \sigma_{1}^{\prime}+\sigma_{3}^{\prime}\right) / 3$ olarak hesaplanmaktadır. $I_{R}$, genleşme indeksi değeri olarak 
adlandırılmıştır ve ampirik olarak elde edilen $Q$ ve $R$ katsayıları ile hesaplanmaktadır. Elindeki üç eksenli deney verisini kullanarak Bolton (1986) tüm kumlar için $\mathrm{Q}=10$ ve $\mathrm{R}=$ 1 değerlerini önermektedir [18]. $A_{\psi}$ değeri ise üç eksenli deneyler ile belirlenen genleşme indeksinin genleşme oranına etkisini gösteren bir katsayıdır. Diğer bir deyişle $A_{\psi} I_{R}$ değeri $\phi_{p}^{\prime}-\phi_{c}^{\prime}$ farkına karşllık gelmektedir. Bolton (1986)'a göre $A_{\psi}$ eksenel simetri şartlarında 3 ve düzlem şekil değiştirme şartlarında ise 5 değerini almaktadır [18].

Bu deneysel çalışma sırasında Bolton (1986) tarafından önerilen ve araştırma çalışmalarında sıklıkla kullanılan Eşitlik 6, model dolgularının $\psi_{p}$ değerlerinin hesaplanması için kullanılmıştır. Daha önce birçok araştırmacı Bolton (1986) tarafından önerilen $Q=10$ ve $R=1$ değerlerinin farklı kumlarda doğru sonuçlar vermediğini tespit etmiş ve her kum için deney yapılmasının gerekliliği belirtilmiştir [25,26]. $Q$ ve $R$ katsayılarının doğru hesaplanabilmeleri için model deneylerinde kullanılan kum üzerinde üç eksenli deneyler yapılmıştır. $\mathrm{Bu}$ çalışmada kullanılan kumlar için geçerli değerler deney malzemeleri bölümünde anlatılacaktır.

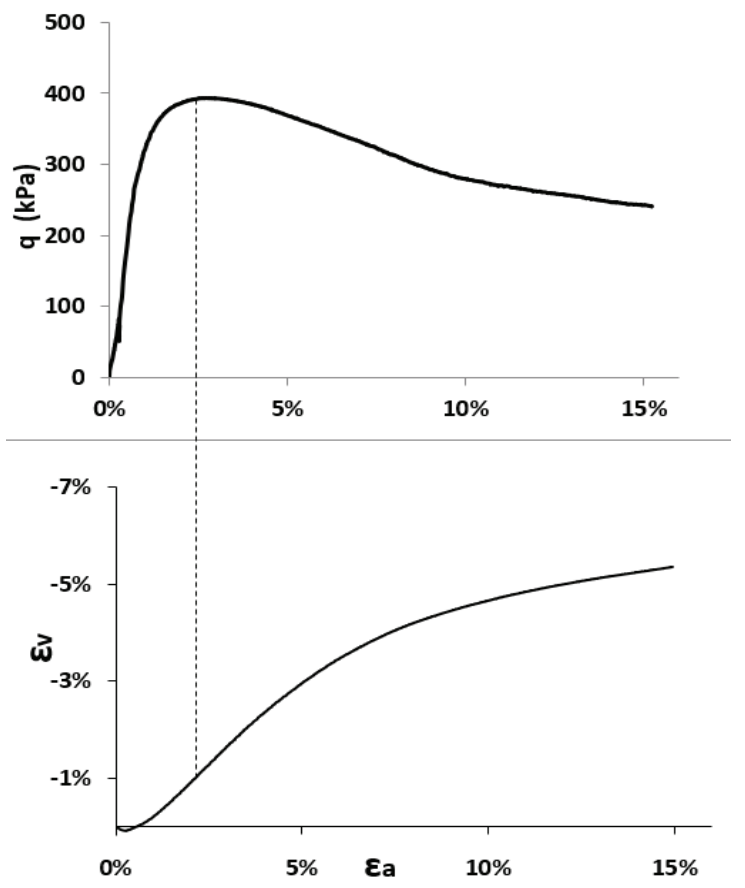

Şekil 1 - Ü̧̧ eksenli deney sırasında deviatorik gerilme (q) ile hacimsel birim şekil değiştirme $\left(\varepsilon_{v}\right)$ büyü̈klüklerinin eksenel şekil değiş̧tirme $\left(\varepsilon_{a}\right)$ ile değişimleri

Yapılan üç eksenli deneyler sonucunda $Q$ ve $R$ katsayılarına ek olarak $r$ katsayısı da elde edilmiştir. Bilindiği üzere genleşme açısı malzeme boyut dağılımı ve mineralojisinin bir fonksiyonu olduğu için üç eksenli ve düzlem şekil değiştirme şartları arasında farklılık göstermemektedir. Fakat içsel sürtünme açısı gerilme şartlarına bağlı olarak değişmektedir $[27,28,29]$. Bunun sebebi $\phi_{p}^{\prime}$ değerinin zeminin sıkılığına ve gerilme izine bağlı olmasıdır. 
Dolayısıyla eksenel simetri şartları için elde edilen $r$ katsayısının, düzlem şekil değiştirme şartları değerine dönüştürülmesi gereklidir. Bu amaca yönelik olarak Hanna (2001) tarafından önerilen ve hesaplanan eksenel simetri şartlarına ait mukavemet parametrelerini düzlem gerilme koşullarına dönüştüren yöntem kullanılmıştır [29]. Yöntemin ayrıntıları Hanna (2001)'de verilmektedir. Hanna (2001) yöntemi kullanılarak deney kumları için geçerli düzlem şekil değiştirmeye uygun $r$ katsayıları elde edilmiştir.

\section{3. İSTINAT DUVARI MODELI VE DENEY SISTEMI}

Çalışma kapsamında aktif göçme yüzeyi geometrilerinin incelenebilmesi için $1 \mathrm{~g}$ şartlarında küçük ölçekli fiziksel model deneyleri yapılmıştır. Bu amaçla kullanılan fiziksel model 20 cm x $25 \mathrm{~cm}$ x $15 \mathrm{~cm}$ boyutlarında bir çerçeveden oluşmaktadır (bkz. Şekil 2). Şekil 3'teki genel görünümde gösterilen istinat yapısını modelleyen alüminyum plakanın yatay ötelenmesi bir çark ile kontrol edilebilmektedir. Modelin üst kısmı, hava basıncı ile granüler zemine düşey olarak sürşarj uygulayabilen ve yükü zemine eşit dağıtabilmek için aynı basınç altında ayrı hareket edebilen 5 adet pnömatik pistondan oluşmaktadır. Pistonlar yük hücresi yardımıyla kalibre edilmiştir. Model boyutları kemerlenme problemi yaşanmayacak şekilde seçilmiştir. Model dolgusunda kemerlenme oluşup oluşmadığ 1 sürşarj basınc1 ile sensör basınçları karşılaştırılarak kontrol edilmiştir. Uygulanan basıncın modelin diğer tarafina aynen iletilebildiği tespit edilmiş ve böylece kemerlenme riskinin olmadığı anlaşılmıştır.

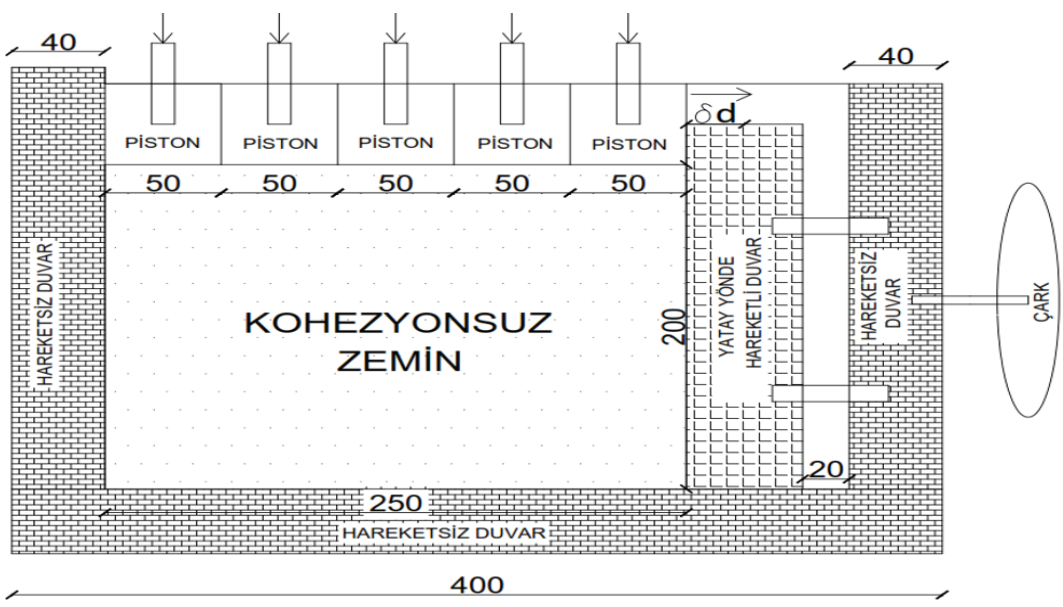

Şekil 2 - Fiziksel model şematik gösterimi

Farklı kum birim hacim ağırlıkları elde edebilmek için zemin bir huni vasıtasıyla farklı yüksekliklerden modele yerleştirilmiştir. İstenilen ağırlık aralığı, kumun dökme yüksekliği ayarlanarak belirlenmiştir. Dolum işlemi tamamlandıktan sonra yerleştirilen dolgu zeminin toplam kütlesi dolgunun test öncesi göreceli sıkılık değerini hesaplamak için ölçülmüştür. Modelin küçük boyutları nedeniyle dolgu sıkılığının homojen olduğu kabul edilmiştir. Zemin tanelerinin duvar hareketi ile yer değiştirmelerini gözlemleyebilmek için çerçevenin ön yüzünde plexiglas malzeme kullanılmıştır (Şekil 2). Model sisteminde, biri çerçeve tabanının ortasında, diğeri hareketli plakanın ön yüzünde olmak üzere iki adet basınç ölçer 
bulunmaktadır. $200 \mathrm{kPa}$ gerilme ölçüm kapasitesine sahip küçük boyutlu gerilme ölçerler deney süresince düşey ve yatay gerilmelerin kaydedilmesi amacıyla kullanılmaktadır (Şekil 4). Deney süresince dolguya etkiyen gerilmeler bu sensörler aracılığıyla takip edilmiş, ortalama gerilme $\left(p^{\prime}\right)$ ve kayma gerilmesi $(q)$ değerleri bu ölçümler kullanılarak hesaplanmıştır. Beklendiği gibi tüm model deneylerinde duvar ötelenme miktarının $(d)$ artışıyla düşey efektif gerilmenin $\left(\sigma_{v}^{\prime}\right)$ değişmediği, yatay efektif gerilmenin $\left(\sigma_{h}^{\prime}\right)$ ise azaldığı gözlenmiştir. Dolguda deney sırasında beliren $q-d$ ilişkisi Şekil 5'te gösterilmektedir.

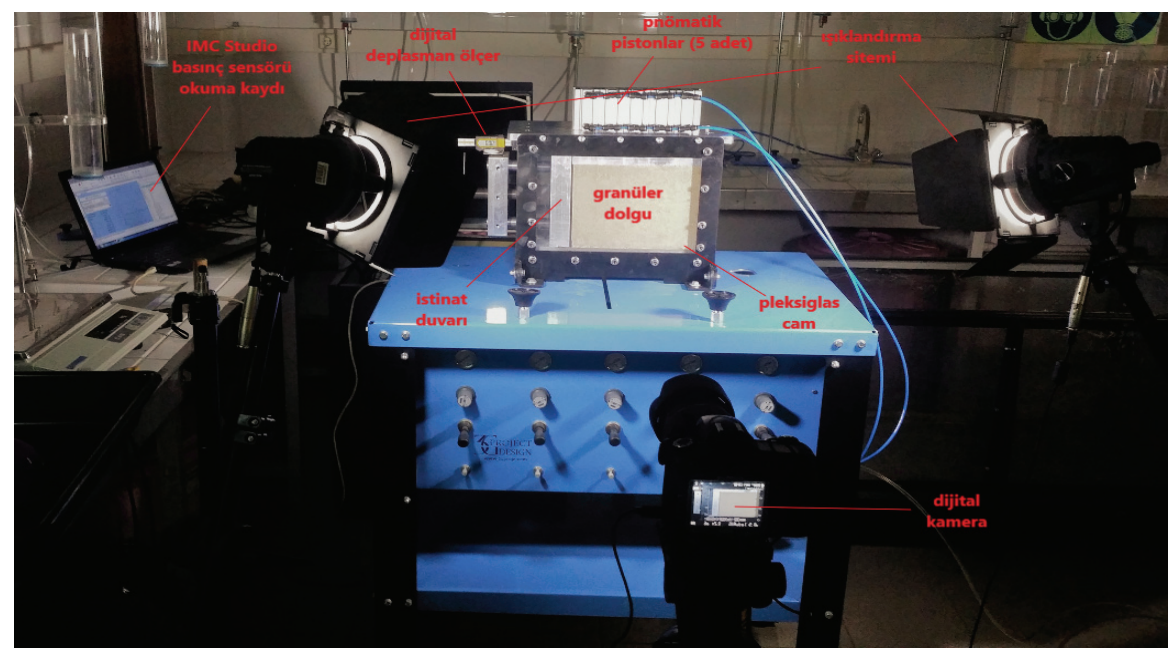

Şekil 3 - Fiziksel Model Genel Görünümü
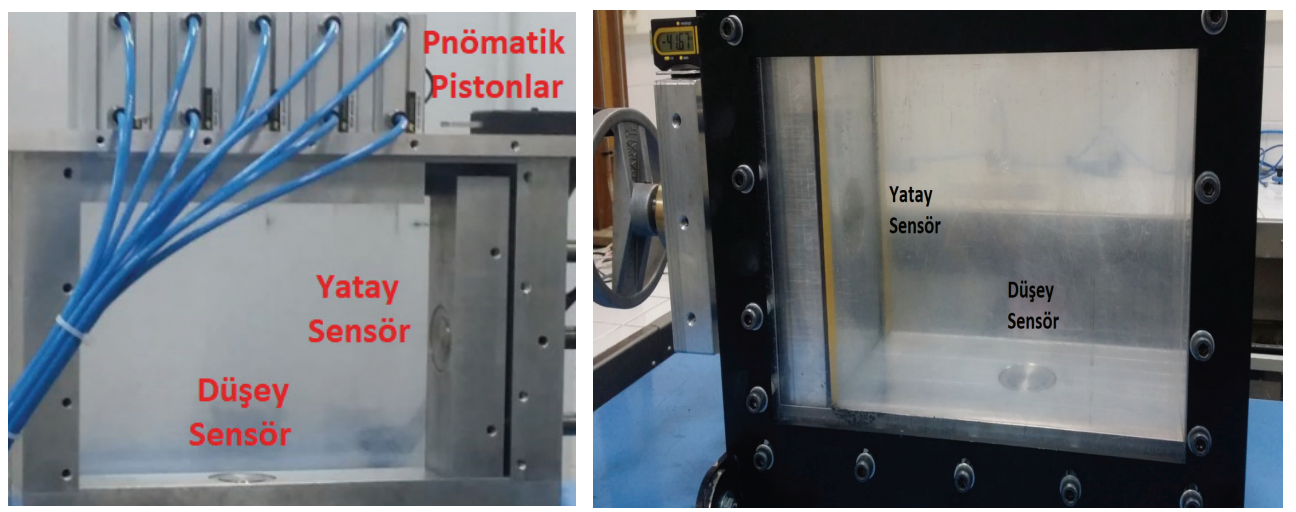

Şekil 4 - Basınç sensörlerinin fiziksel model üzerindeki konumu

Duvarın ötelenme miktarının gözlenebilmesi için duvar arka yüzüne dijital bir sensör yerleştirilmiştir. Deneyler esnasında istinat duvarı, el ile döndürülebilen çark yardımıyla 0.5 $\mathrm{mm} / \mathrm{s}$ sabit hızında yatay yönde hareket ettirilmektedir. Duvar hareketleri başlangıç durumundan göçme durumuna kadar bir sabitleyiciye oturtulmuş 6000 x 4000 yüksek 
çözünürlüklü dijital kamera ile her $0.1 \mathrm{~mm}$ deplasman için fotoğraflanmıştır. Kamera ile fiziksel model arasındaki mesafenin, kamera odağının ve doğrusallığının her testte sabit olmasına dikkat edilmiştir. Yüksek kaliteli fotoğraf çekimi için özel 1şıklandırma sistemi kullanılmıştır. Böylece deney sırasında duvarın yatay hareketi, dolgudaki düşey ve yatay gerilmeler ve zemin tanelerinin yer değiştirmesi başlangıç durumundan göçme durumuna kadar kaydedilmiştir.

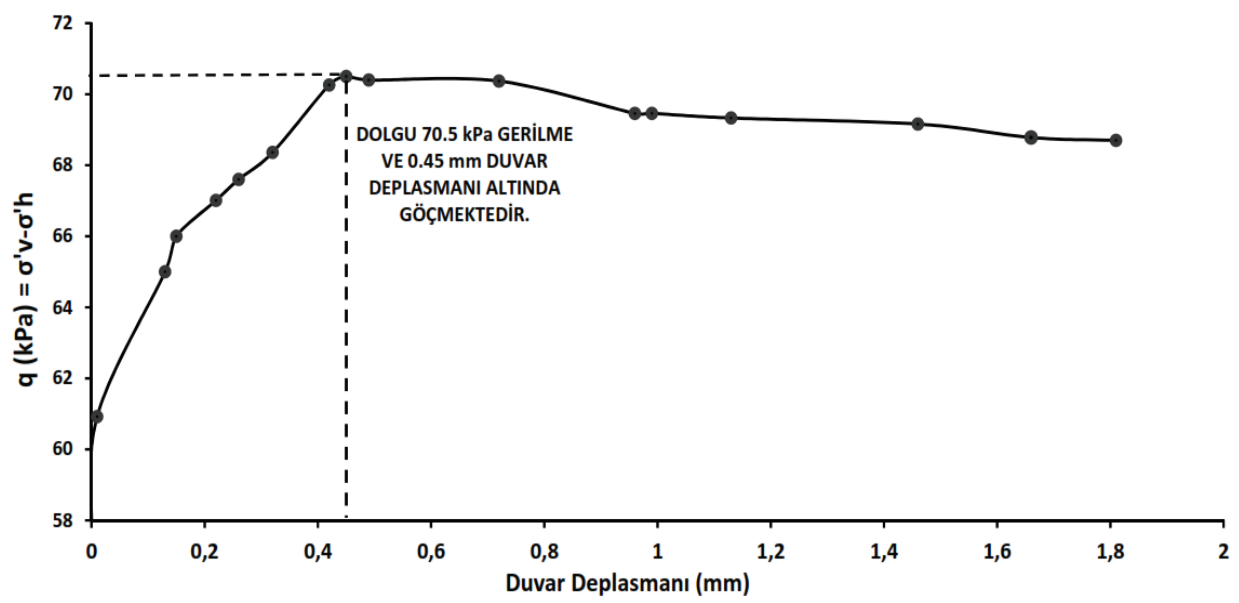

Şekil 5 - Model deneyi sırasında kayma gerilmesinin duvar ötelenmesi ile değişimi

\section{DENEYLERDE KULLANILAN KUMLARIN ÖZELLIKKLERİ}

Bu bölümde model çalışmalarında kullanılan kumların fiziksel ve mekanik özelliklerinin deney sonuçları sunulacaktır.

\subsection{Fiziksel Özellikler}

Deneylerde İstanbul'un farklı bölgelerindeki kum ocaklarından alınmış, alındığı bölgeye göre isimlendirilen Akpınar, Şile ve Kilyos kumları kullanılmıştır. Kumlar, laboratuvara getirildikten sonra yıkanmış ve 4 No'lu elek üzerinde kalan (çakıl) ile 200 No'lu eleği geçen (kil ve silt) tane boyutlarından arındırılmıştır. Şekil 6'da bu kumların granülometri eğrileri verilmektedir.

Elek analizi sonuçlarına göre her kum için ortalama tane çapı $\left(\mathrm{D}_{50}\right)$, ortalama üniformluk katsayısı $\left(\mathrm{C}_{\mathrm{u}}\right)$, ortalama derecelenme katsayısı $\left(\mathrm{C}_{\mathrm{c}}\right)$ parametreleri belirlenmiştir. Zeminlerin özgül ağırlık, maksimum ve minimum boşluk oranı değerleri ASTM standartlarına uyularak laboratuvar deneyleri ile elde edilmiştir. Her kum tipinin farklı kısımlarından toplam 50 adet tane rastgele seçilerek bunların dijital mikroskop kamerası ile fotoğrafları çekilmiş, ImageJ programı ile analizleri yapılarak tane şekli belirlenmesinde kullanılan ortalama küresellik ( $S_{\text {ort }}$ ) ve yuvarlaklık $\left(\mathrm{R}_{\text {ort }}\right.$ ) değerleri elde edilmiştir (Şekil 7). Seçilen tane sayısı büyük sayılar yasası (Moore ve McCabe 2003) göz önünde bulundurularak seçilmiştir [30]. Bulunan değerler, Krumbein ve Sloss (1963) tarafindan önerilen tane şekli tablosu ile karşılaştırılmıştır [31]. 


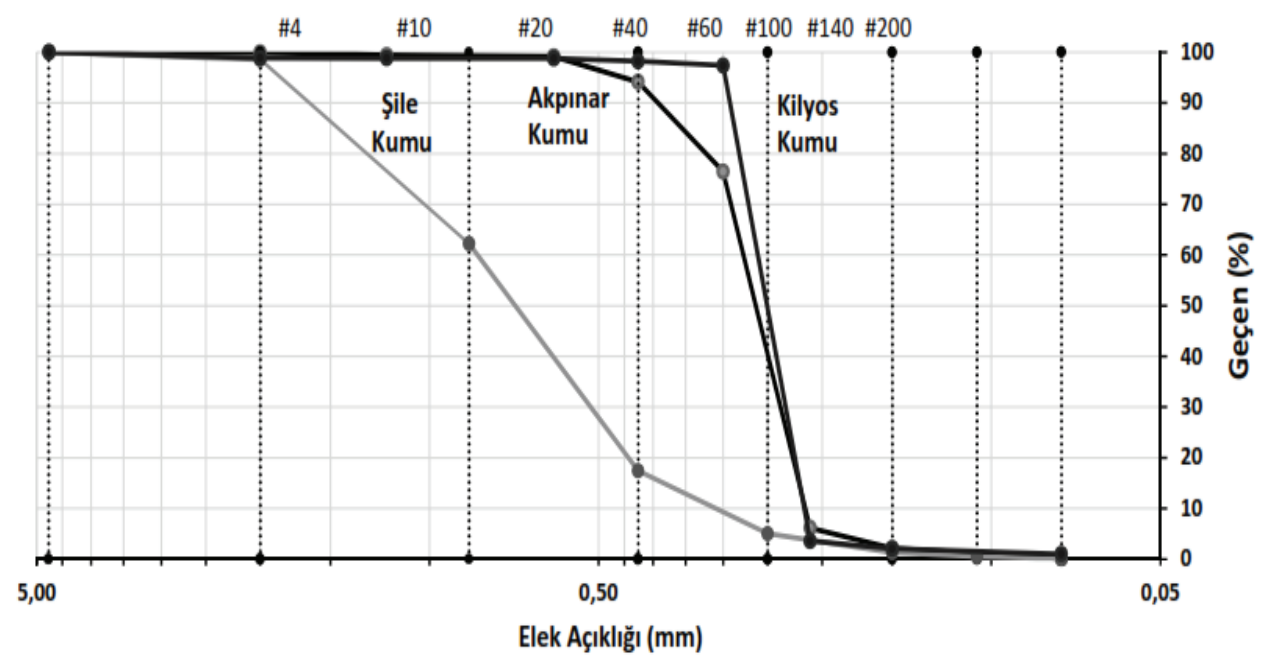

Şekil 6 - Çalışmada kullanılan kumların elek analizleri

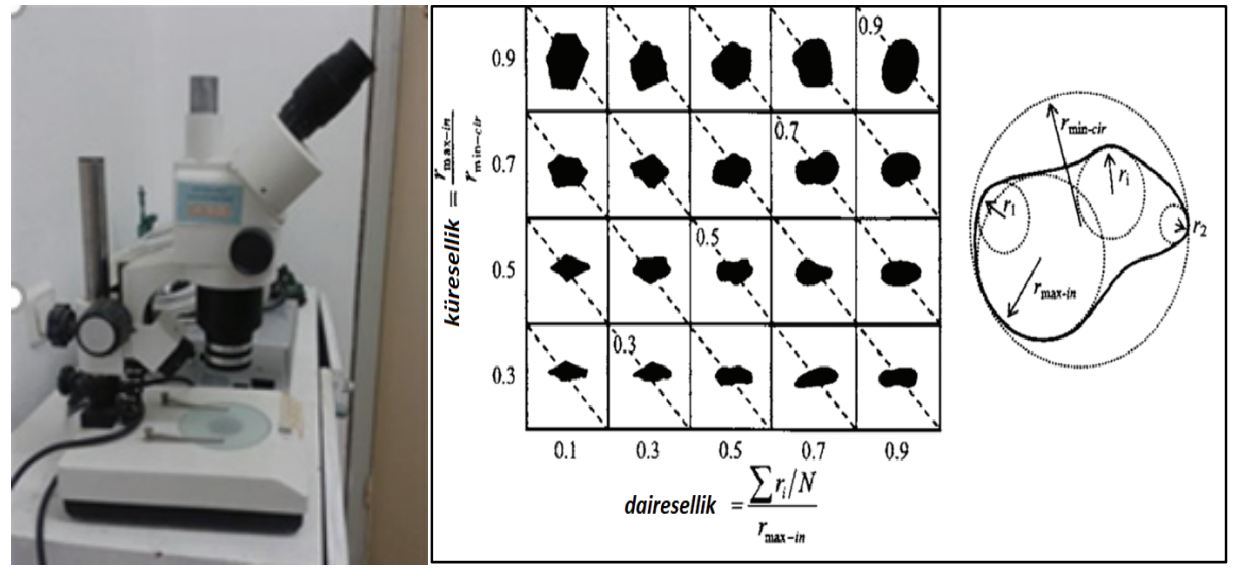

Şekil 7 - Tane şekli analizinde kullanılan Mshot model dijital mikroskop kamerası ve Krumbein ve Sloss (1963) tarafindan önerilen tane şekli diyagramı

Kumların laboratuvar deneyleri ile tespit edilen tüm fiziksel özellikleri Çizelge 1'de verilmektedir. Plexiglas ile Şile kumu arasındaki sürtünme açısı kesme kutusu deneyleri ile yaklaşık $\delta^{\prime}=22^{0}$ olarak ölçülmüştür. Göçme yüzeyi geometrisi oluşumunda etkin olan sürtünmeyi azaltmak için, plexiglas yan duvarlara şeffaf ve yüksek birim hacim ağırlıklı polietilen tabakalar yerleştirilmiştir. Ayrıca, plexiglas üzerinde 'Petrochem' marka saydam silikon yağ kullanılmıştır. Uygulama sonrası bu yağ yüksek sıcaklık altında kurutularak ve deney öncesi yeterli süre beklenerek zemin tanelerine yapışması önlenmiştir. Silikon yă̆ ve plexiglas kullanımı ile sürtünme açısı $\delta^{\prime}=12^{0}$ civarına düşürülmüştür. Model duvar yüksekliği 
ile deneylerde kullanılan kumların boyutları karşılaştırıldığında problem sonuçlarını etkileyebilecek ölçek sorunun olmadığı görülmektedir. Zira çalışmada temiz kumlar kullanılmıştır ve gözlenen davranış kum veya çakıl kohezyonsuz tüm dolgu malzemelerinde gözlenecek davranış ile aynıdır. Gerçek boyutta bir istinat ölçeği düşünüldüğünde, model duvarı yüksekliğinin kumun $\mathrm{D}_{50}$ büyüklüğüne oranı kaba kum-ince çakıl boyutlarına karşılık gelmektedir ve bu durum mekanik davranışta değişikliklere sebep olmayacaktır.

Çizelge 1 - Çalışmada kullanılan kumların fiziksel Özellikleri

\begin{tabular}{cccc}
\hline Fiziksel Özellik & $\begin{array}{c}\text { Akpınar } \\
\text { Kumu }\end{array}$ & $\begin{array}{c}\text { Şile } \\
\text { Kumu }\end{array}$ & $\begin{array}{c}\text { Kilyos } \\
\text { Kumu }\end{array}$ \\
\hline Ortalama tane büyüklüğü $\left(\mathrm{D}_{50}\right)$ & 0.27 & 0.71 & 0.26 \\
Üniformluk katsayısı $\left(\mathrm{C}_{\mathrm{u}}\right)$ & 1.23 & 2.80 & 1.24 \\
Süreklilik katsayısı $\left(\mathrm{C}_{\mathrm{c}}\right)$ & 0.97 & 1.12 & 0.97 \\
Özgül ağırlık $\left(\mathrm{G}_{\mathrm{s}}\right)$ & 2.63 & 2.61 & 2.66 \\
Maksimum boşluk oranı $\left(\mathrm{e}_{\text {maks }}\right)$ & 0.87 & 0.78 & 0.77 \\
Minimum boşluk oranı $\left(\mathrm{e}_{\mathrm{min}}\right)$ & 0.58 & 0.52 & 0.44 \\
Ortalama küresellik $\left(\mathrm{S}_{\text {ort }}\right)$ & 0.716 & 0.551 & 0.743 \\
Ortalama yuvarlaklık $\left(\mathrm{R}_{\text {ort }}\right)$ & 0.728 & 0.757 & 0.759 \\
\hline
\end{tabular}

\subsection{Deneylerde Kullanılan Kumların Mekanik Özellikleri}

Kumların mekanik özelliklerinin elde edilmesi amacıyla Geocomp marka üç eksenli deney düzeneği kullanılarak laboratuvarda her kum için değişken sıkılık ve çeper basınçlarında 12 adet $\mathrm{K}_{\mathrm{o}}$ konsolidasyonlu ve drenajlı deney yapılmıştır. Numunelerin farklı sıkılıkta hazırlanabilmeleri için kuru şartlarda kum yağdırma tekniği kullanılmış, doyurma aşamasını hızlandırabilmek için $\mathrm{CO}_{2}$ kullanılmıştır. Şekil 8'de oluşturulan deney numunesi aşamaları görülmektedir. Deney sonuçları analiz edilerek $\phi_{p}^{\prime}, p_{f}^{\prime}$ ve $\psi_{p}$ değerleri her deney için tespit edilmiştir. Numunelerin göreceli sıkılığı $\left(I_{D}\right)$ bilgisi de kullanılarak tüm deneylerin sonuçları Bolton (1986) gerilme-genleşme denkleminde yer alan Q ve R parametreleri her kum için ayrı olarak hesaplanabilmiştir. $\psi_{p}-\phi_{p}^{\prime}$ arasındaki ilişki grafiksel olarak çizilmiş ve Vaid ve Sasitharan (1992) tarafından açıklanan yoldan üç eksenli için geçerli $r$ değeri $\left(r_{t x}\right)$ ve $\phi^{\prime}{ }_{c}$ elde edilmiştir [32]. Deneylerde kullanılan tüm kum numuneleri mineralojik olarak kuvars yapıda olduğundan kritik durum sürtünme açıları birbirlerine yakın çıkmakla birlikte, daha köşeli tane şekline sahip Şile kumunda sürtünme açısının daha yüksek olduğu görülmektedir. Son olarak, Hanna (2001) yöntemi kullanılarak $r_{t x}$ değerleri düzlem şekil değiştirme şartlarında geçerli $r$ değerlerine $\left(r_{p s}\right)$ dönüştürülmüştür [29].

Tüm kumların hesaplanan mekanik parametreleri Çizelge 2'de verilmiştir. Çizelge 2'den görülebileceği üzere deneylerden elde edilen $Q$ ve $R$ değerleri Bolton (1986) tarafindan önerilen değerlerden farklıdır ve her kum numunesinde değişmektedir. 


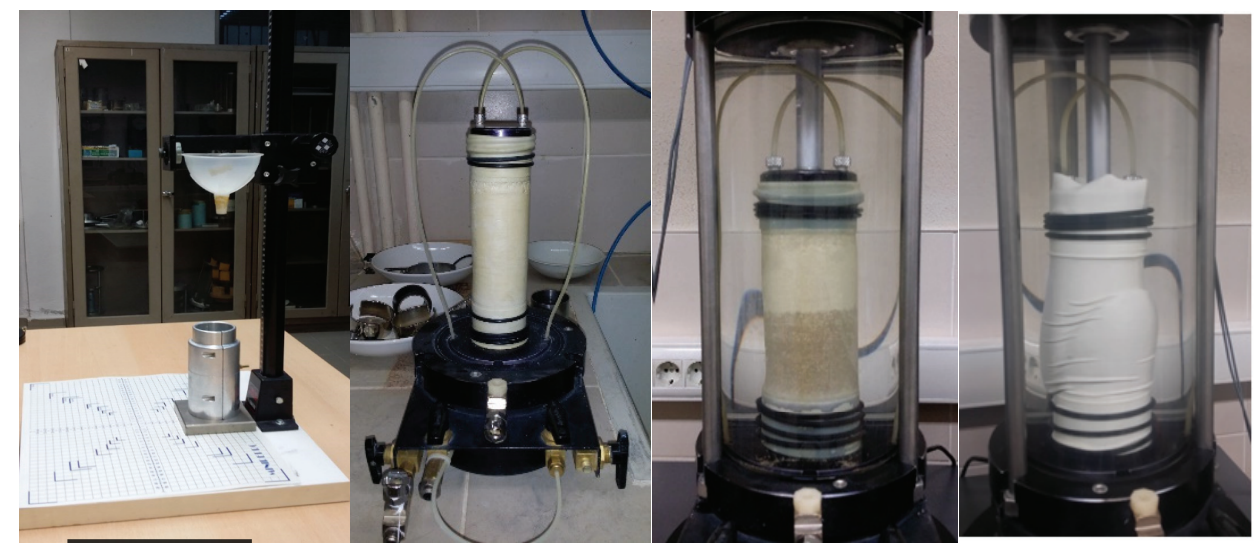

Şekil 8 - Üç eksenli deneylerde kullanılan numunelerin oluşturulması ve göçme durumu

Çizelge 2 - Çalışmada kullanılan kumların mekanik özellikleri

\begin{tabular}{cccc}
\hline Mekanik Özellik & $\begin{array}{c}\text { Akpınar } \\
\text { Kumu }\end{array}$ & $\begin{array}{c}\text { Şile } \\
\text { Kumu }\end{array}$ & $\begin{array}{c}\text { Kilyos } \\
\text { Kumu }\end{array}$ \\
\hline $\begin{array}{c}\text { Eksenel simetri koşulları için genleşme açısının tane } \\
\text { kilitlenmesine etkisi }\left(r_{t x}\right)\end{array}$ & 0.39 & 0.38 & 0.48 \\
Düzlem gerilme koşulları için genleşme açısının tane & & & \\
kilitlenmesine etkisi $\left(r_{p s}\right)$ & 0.66 & 0.90 & 0.91 \\
Bolton (1986) genleşme indeksi $Q$ katsayısı & 9.08 & 8.22 & 7.80 \\
Bolton (1986) genleşme indeksi $R$ katsayısı & 1.0 & 0.15 & -1.40 \\
Kritik durum sürtünme açısı $\left(\phi_{c}^{\prime}\right)\left({ }^{\circ}\right)$ & 33.0 & 34.7 & 33.7 \\
\hline
\end{tabular}

\section{PARÇACIK GÖRÜNTÜ HIZI ÖLÇÜM (PGHÖ) YÖNTEMİ İLE GÖRÜNTÜ ANALIZI}

Son yıllarda görüntü işleme tekniklerinin gelişimi ile birlikte çeşitli analiz yöntemleri kullanılarak model dolgusunun hareketlerinin oluşturduğu vektör uzayı tespit edilmektedir. $\mathrm{Bu}$ yöntemler içinde en güncel olan ve tercih edilen yöntem parçacık görüntülü hızı ölçümü (PGHÖ) yöntemidir. PGHÖ yöntemi akışa müdahalesiz alansal hız ölçüm yöntemidir. Daha önce de Niedostatkiewicz v.d. (2011), Lesniewska v.d. (2011), Pietrzak ve Lesniewska (2012), Tehrani v.d. (2012) ve Altunbaş v.d. (2017) gibi araştırmacılar bu yöntemi kullanarak fiziksel model çalışmaları yapmışlardır [33, 34, 35, 36].

Bu çalışmada da benzer şekilde model dolgusunun şekil değiştirmeleri PGHÖ yöntemi kullanılarak tespit edilmiştir. Bu amaçla deneyler süresince yüksek frekansta fotoğraflar çekilmektedir. Deney esnasında çekilen fotoğraflar, zemin tanelerinin büyük deformasyonları için MATLAB tabanlı bir görüntü analiz modülü olan geoPIV yazılımı kullanılarak işlenmektedir [37]. GeoPIV yazılımı, PGHÖ yönteminin geoteknik problemlerine uygulanması için geliştirilmiştir. Geo-PIV programını kullanabilmek için 
duvar hareketi ile zeminde oluşan yer değiştirmelerin yüksek çözünürlüklü dijital fotoğrafları ardışık olarak çekilmektedir. Oluşabilecek ölçüm hatalarının en aza indirilmesi amacıyla kamera deney modelinin plastik cam yüzüne dik şekilde yerleştirilmiştir. Fotoğraf çekimi esnasında oluşabilecek ufak titreşimlerin engellenmesi amacıyla, fotoğraf makinası üç ayaklı sehpa üzerine sabitlenmiştir. Yazılım fotoğraf karelerinde incelenecek alanı kutucuklara böler ve her bir kutucuğun piksel yoğunluğunu matris olarak ifade eder. Analizdeki referans görüntü duvarın yer değiştirmesinden önce çekilmiş olan fotoğraftır. GeoPIV algoritması hareket halinde çekilen sonraki fotoğraflarda referans görüntüdeki kutucuğu arar ve en yüksek benzerlik yakalanan bölge ile başlangıç bölgesini birleştirerek hareket vektörünü elde eder. Böylelikle yer değiştirme vektör uzayı tanımlanır (Şekil 9). Yazılım, elde edilen vektör uzayını yoğunluğa göre değişen pikselde renk haritaları ile görselleştirebilmektedir. Buna göre analiz edilen her resim için hacimsel ve kayma yer değiştirmeleri tespit edilebilmektedir. Böylece incelenen bölgede tüm yer değiştirmeler elde edilmekte, lokalizasyon davranış1 tespit edilmekte ve göçme yüzeyinin oluşumu net bir biçimde gözlenmektedir.
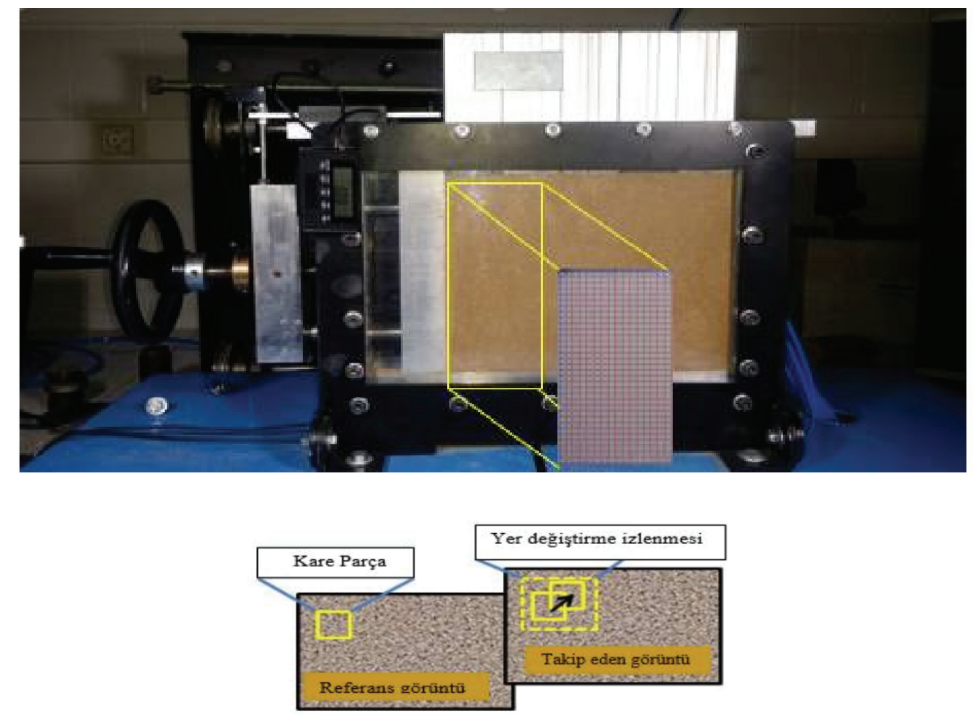

Şekil 9 - GeoPIV analizinde seçilen bölge ve yer değiştirme vektörünün tanımlanması

\section{KAYMA BANDI GEOMETRILERININ GENLEŞME DAVRANIŞI İLE İLIŞKISİ}

Duvar arkasındaki dolgu zeminin göçme durumundaki kayma yer değiştirmelerinin dağılımı, tüm deneyler için PGHÖ analizi ile ortaya çıkartılmıştır. Renk ölçekli olarak görselleştirilen PGHÖ analiz çıktıları incelendiğinde, yüksek kayma birim şekil değiştirmelerinin bir bant içine toplandığ 1 görülmektedir. Sürşarjlı ve sürşarjsız model deney sonuçlarının göçme anı için karşılaştırıldığı Şekil 10'da kayma bandının ve hareket halinde olan kayma kamasının rahatlıkla tanımlanabileceği örnekler sunulmaktadır. Analiz sonuçları incelendiğinde çok düşük gerilmeler altında sürşarjsız yapılan deneylerde, yüksek gerilmeler altında yapılan sürşarjlı deneylerde oluşanlara oranla daha dik kayma bantları elde edildiği görülmektedir. Burada dik kayma bandı tabiriyle ifade edilen gözlenen bantların daha düşeye yakın olmaları ve model duvara yakın oluşarak daha küçük kayma kamalarına sınır olmalarıdır. Diğer 
yandan, gerilme ortamının sabit tutulması halinde artan sıkılık oranlarının daha dik kayma bantları oluşumuna yol açtı̆̆ anlaşılmaktadır. Altunbaş v.d. (2017) sürşarjsız ve çok düşük gerilme şartlarında yaptıkları model deneylerde de aynı davranışı gözlediklerini rapor etmişlerdir [26]. Bu çalışmada da gözlemler model deneylerinde kullanılan tüm kumlar için aynı şekildedir (bkz. Şekil 10). Tüm bu etkenler $\psi_{p}$ ile ilişkilidir. Göçme yüzeyinin geometrisi gibi $\psi_{p}$ değeri de gerilme ortamına ve zeminin sıkılığına bağlı değerler almaktadır. Ortam gerilmesi arttıkça $\psi_{p}$ azalmakta, sıkılık arttıkça $\psi_{p}$ yükselmektedir. Buradan göçme geometrisi ve $\psi_{p}$ arasında yakın bir ilişki olduğu anlaşılmaktadır.

Sürşarj yüklerinin yüksek olduğu ve/veya kumun daha gevşek yerleştirildiği deneylerde kayma kamasının daha az belirgin olduğu ve kayma bandının daha geniş olduğu izlenmektedir. Bu gözlem daha önce benzer çalışmalar yapmış araştırmacıların bulguları ile uyumludur [33, 34, 35, 36]. Zira sıkı zemin davranışı (düşük gerilme, düşük boşluk oranı) daha net kayma bantlarına, gevşek zemin davranışı (yüksek gerilme, yüksek boşluk oranı) daha kalın kayma bantlarına neden olmaktadır.

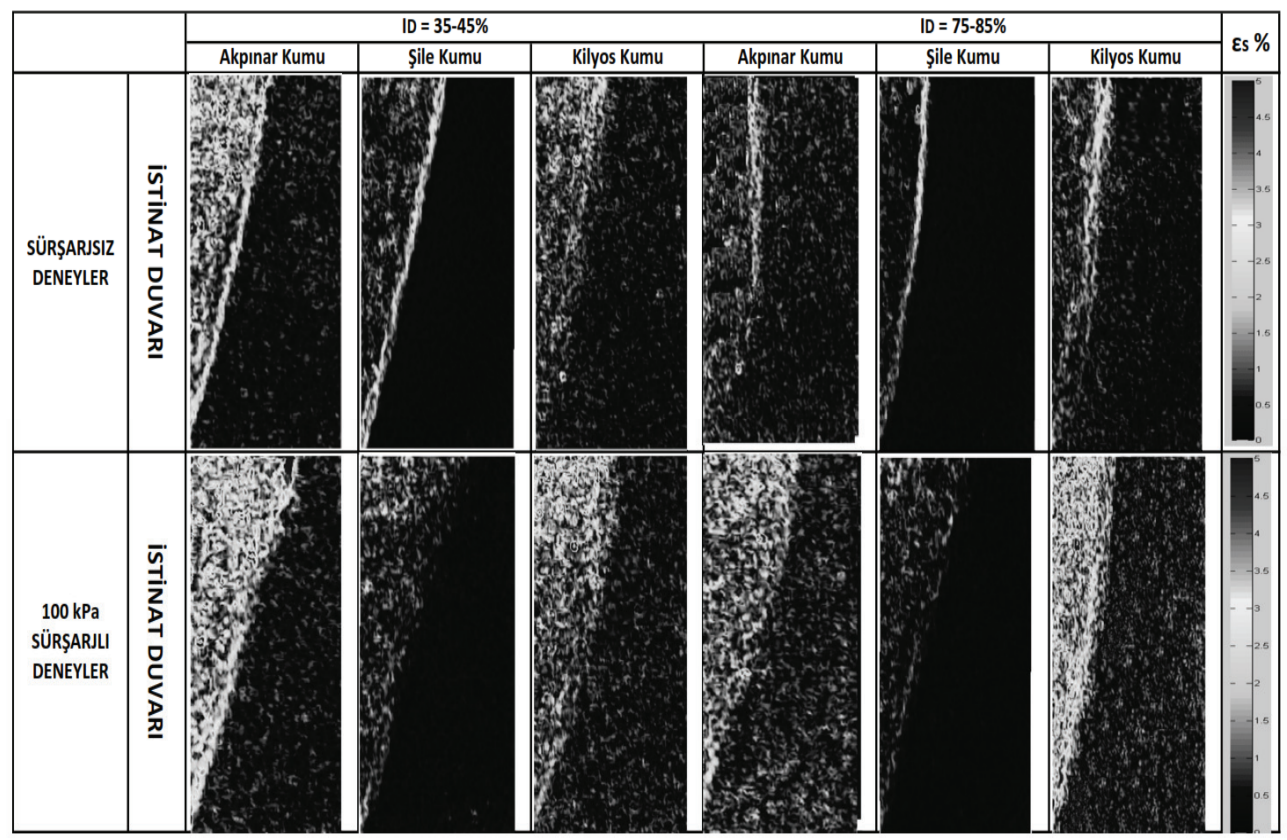

Şekil 10 - Farkl gerilme ve sıkllikşartlarındaki model dolgularının PGHÖ ile çözümlenmesi sonucunda belirlenen kayma birim yer değiștirmeleri

Her deney için hesaplanan $\psi_{p}$ ile göçme yüzeyi geometrileri arasında ilişki kurabilmek için, PGHÖ analizi ile elde edilen kayma bandı nicelleştirilmeleri gerekmektedir. Bunun için başlangıç noktasının model duvarın dolgu tarafında en üst noktası olduğu bir koordinat sistemi oluşturulmuştur. Bu koordinat düzlemi duvar yüksekliği $\left(H_{w}\right)$ ile normalize edilerek birimden bağımsız hale getirilmiştir. Düzlemde göçme yüzeylerinin dış yüzeylerinin yatay 
ve düşey koordinatları belirlenmiş böylece göçme anındaki kayma yüzeyleri geometrik olarak ortaya çıkartılmıştır (Şekil 11).
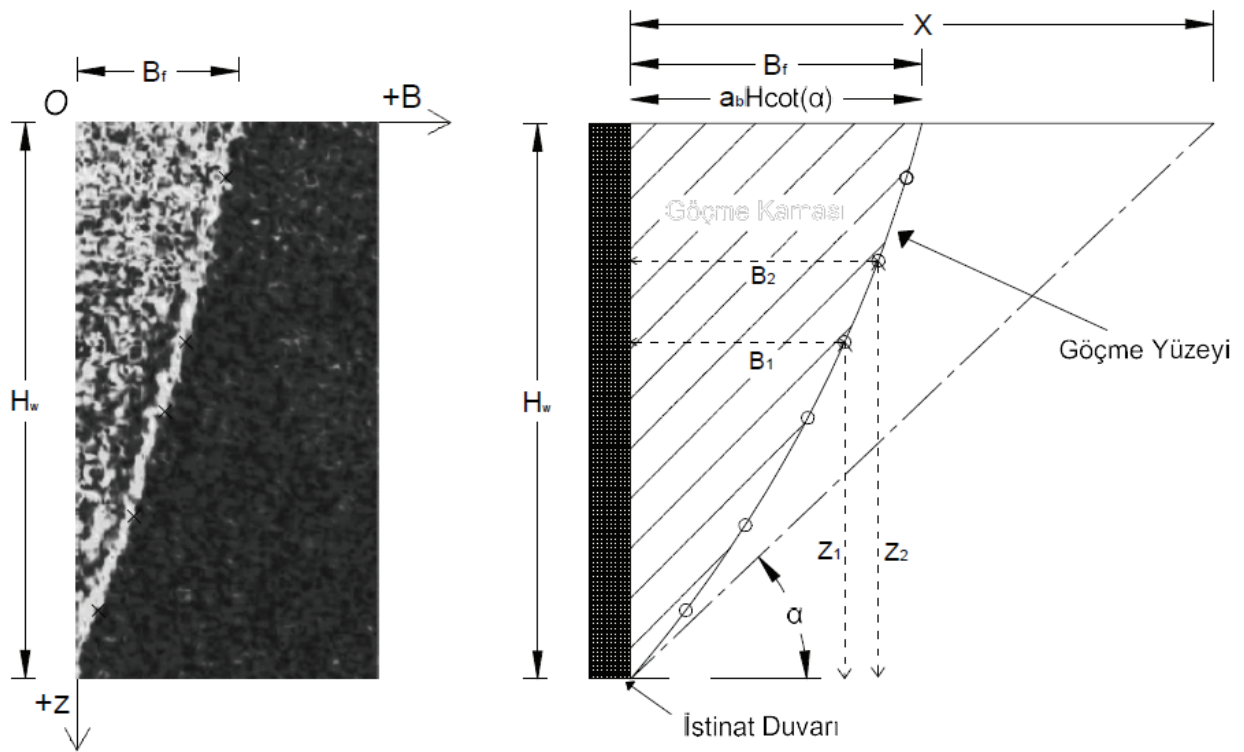

Şekil 11 - PGHÖ analizi ile elde edilen göçme yüzeyi geometrisinin matematiksel olarak tanımlanması

Altunbaş v.d. (2017), sürşarj etkisinin olmadığ 1 ve sadece farklı başlangıç göreceli sıkılık değerinin kullanıldığı model deney çalışmalarında göçme yüzeyi geometrisinin parabolik olarak

$z=\left(\left[\left(a_{b}-1\right) /\left(a_{b}^{2} H_{w}\right)\right] \tan ^{2}(\alpha)\right) B^{2}-\tan (\alpha) B+H_{w}$

eşitliği ile tanımlanabileceğini öne sürmüştür [26]. Bu bağıntıda, Şekil 11'de tanımlandığ1 gibi $\mathrm{H}_{\mathrm{w}}$ duvar yüksekliğini, $z$ değeri incelenen noktanın başlangıç noktasına göre düşey koordinatını, $B$ değeri incelenen noktanın başlangıç noktasına göre yatay koordinatını göstermektedir. $\alpha$ değeri kayma bandının topuğunda yer alan başlangıç kısmının yatay ile yaptığı açıdır. $a_{b}$ ise Şekil 11 'de gösterilen $B_{f}$ ve $X$ mesafelerinin oranıdır $\left(B_{f} / X\right)$. $B_{f}$, duvar ile göçme yüzeyinin arasındaki yatay mesafenin dolgu yüzeyindeki değeri, $X$ ise yatay ile $\alpha$ açısı yapan ve duvarın topuğundan başlayan doğrunun dolgu yüzeyinde model duvar ile yaptığı yatay mesafedir.

Eşitlik 7'de görüldüğü gibi göçme yüzeyinin iki karakteristik özelliği vardır. Bunlar göçme yüzeyinin başlangıç eğimi $(\alpha)$ ve kayma bandının dolgu yüzeyine ulaştığı noktanın normalize koordinatıdır $\left(a_{b}\right)$. Göçme yüzey geometrisinin öngörülebilmesi bu iki geometrik özelliğin değerlerinin hesaplanabilmesine bağlıdır. Yukarıda belirtildiği gibi göçme yüzeyi 
geometrisinin dolgunun $\psi_{p}$ değerine bağlı olduğu öngörüldüğ̈̈ için her iki değerin $\psi_{p}$ ile değişimi elde edilmiştir (Şekil 12 ve Şekil 13).

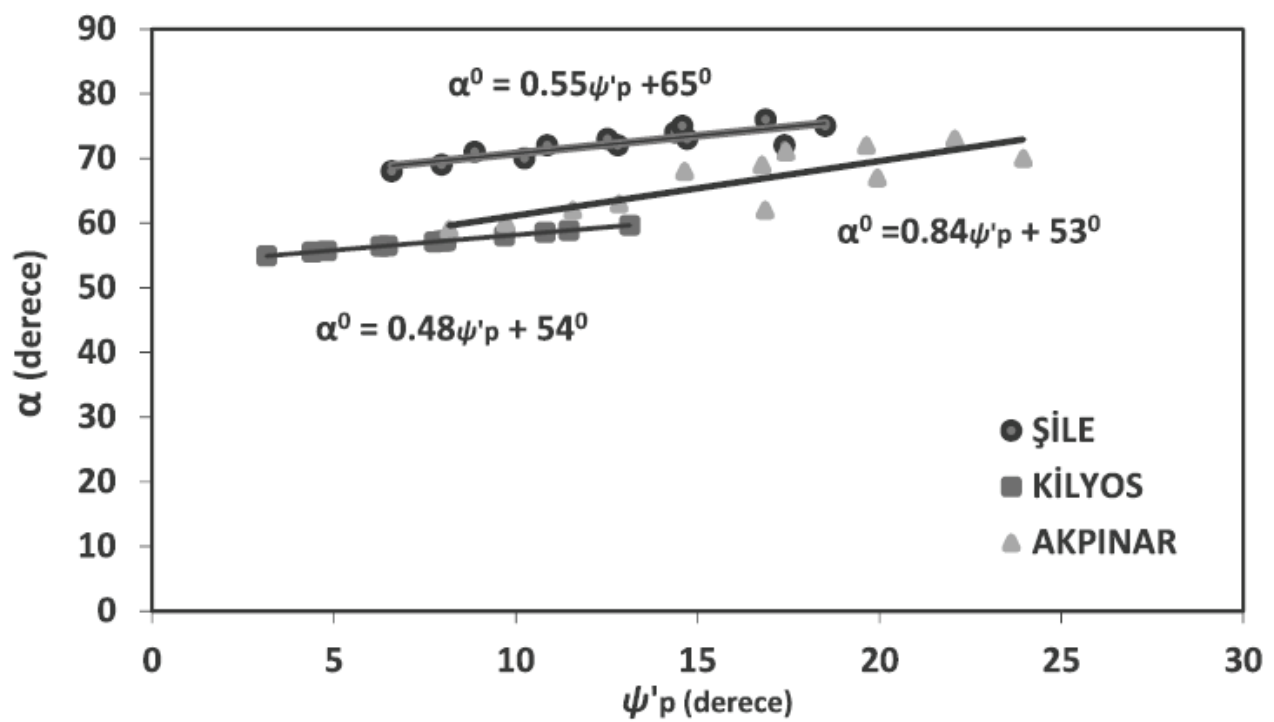

Şekil 12 - Her üç kum için model deneylerden elde edilen $\boldsymbol{\alpha}-\boldsymbol{\psi}_{\boldsymbol{p}}$ iliş̧kileri

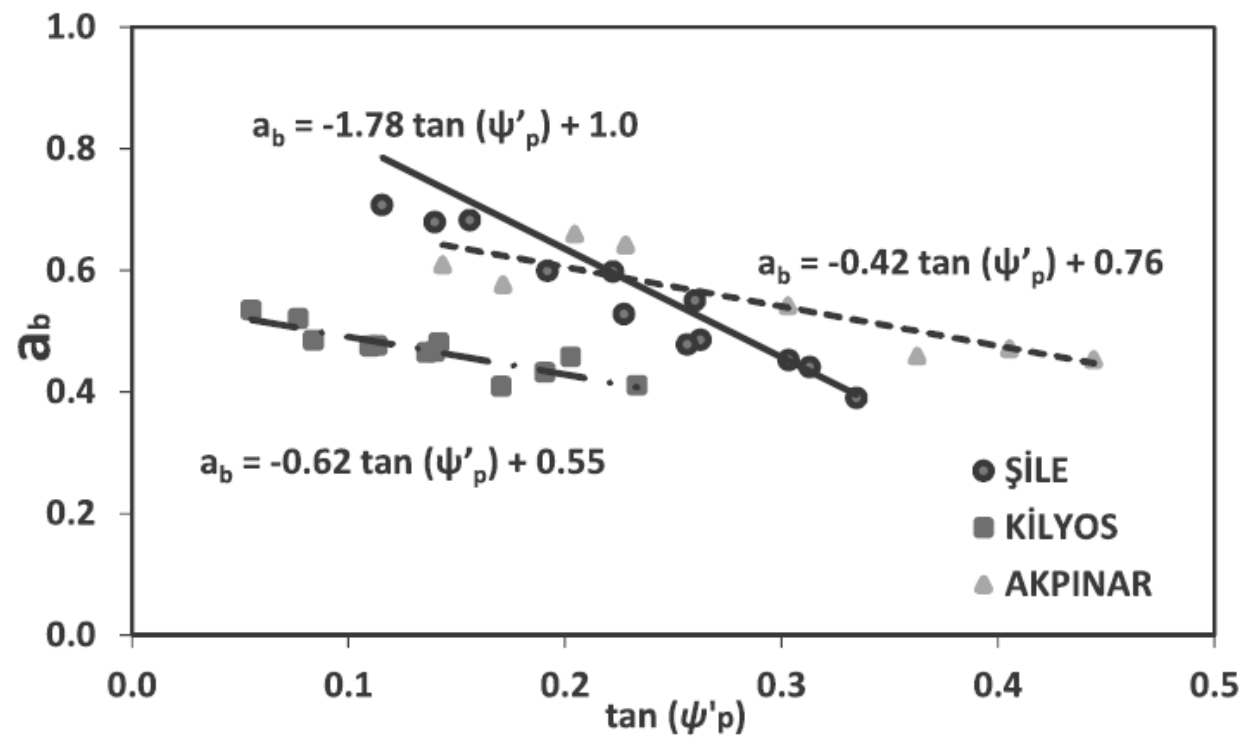

Şekil 13 - Şile, Akpınar ve Kilyos kumları için $a_{b}-\tan \psi_{p}$ ilişkisi 


\section{TARTIŞMA}

Şekil 12'den görülebileceği gibi artan genleşme etkisi göçme yüzeyinin eğimini arttırmaktadır. Bu davranış incelenen tüm kumlar için geçerlidir. Farklı kumların sahip olduğu $\alpha$ değerleri incelendiğinde, en köşeli tane geometrisine sahip Şile kumunun (Çizelge 1) $\alpha$ değerlerinin diğer iki kumun sahip olduklarından daha yüksek olduğu görülmektedir. $\alpha$ değerleri açısından Şile kumunu Akpınar kumu takip etmektedir. Beklendiği gibi Akpınar kumu Kilyos kumundan daha köşeli tanelere sahiptir. Fakat Akpınar ve Kilyos kumlarının Çizelge 1'de verilen $\mathrm{C}_{\mathrm{u}}$ ve $\mathrm{C}_{\mathrm{c}}$ değerleri ile Şekil 6'da sunulan tane boyutu dağılım eğrileri neredeyse aynıdır. Ayrıca ortalama tane boyutu da $\left(\mathrm{D}_{50}\right)$ yaklaşık olarak aynıdır. Bu sebeple tane şeklinin köşeli olmasının daha yüksek $\alpha$ değerlerine sebep olduğu düşünülmektedir. Buna bağlı olarak taneleri küresele yakın olan ve elek analizine göre yalnızca iki farklı elekten geçebilen tane çapı bulunduran kötü derecelenmiş Kilyos kumunda daha düşük $\alpha$ değerli göçme yüzeyleri oluşmaktadır.
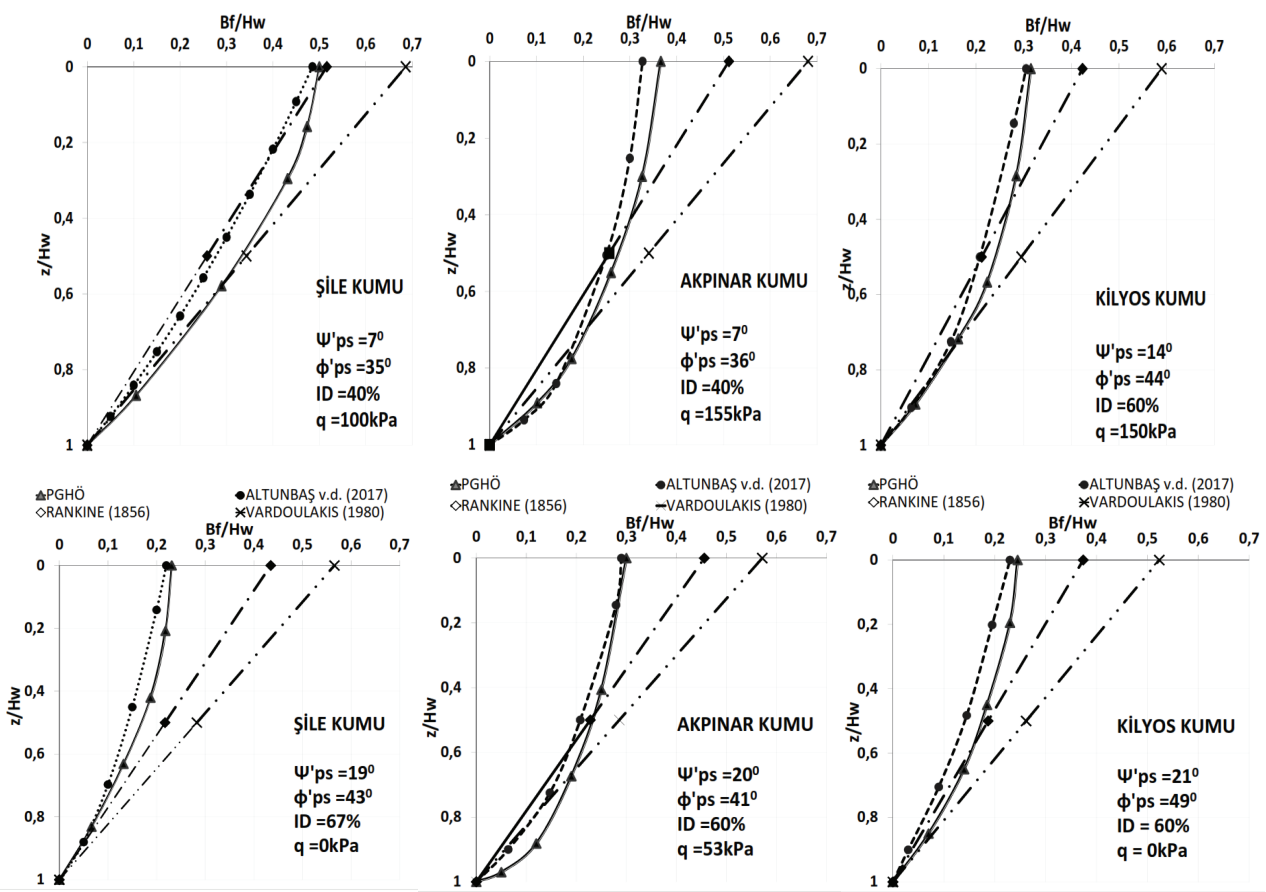

Şekil 14 - Dolguların farklı bă̆ıntılar ile hesaplanan göçme yüzeyi geometrilerinin PGHÖ yöntemi ile karşılaştırılması

Şekil 13'te göçme yüzeyinin eğriliği hakkında bilgi verilmektedir. Bunun sebebi $a_{b}$ değerinin Şekil 11'de gösterildiği gibi $B_{f}$ ve $X$ değerlerinin oranı olmasıdır. Şekil $13 a_{b}$ oranının $\psi_{p}$ ile değişiminin hızı açısından incelendiğinde Şile kumunun $a_{b}-\tan \psi_{p}$ ilişkisinin diğer iki kumdan farklı eğime sahip olduğu görülebilir. Yukarıdaki paragrafta da açıklandığı gibi Şile 
kumu Akpınar ve Kilyos kumlarına nispeten düzgün tane dağılımlı bir kumdur. Buna göre mevcut sonuçlar kapsamında düzgün tane boyut dağılımlı kumlarda genleşim davranışının göçme yüzeyi eğriliğini daha çok etkilediği ve arttırdığı öne sürülebilir. Buna mukabil yaklaşık aynı tane dağılım özelliklerine sahip Akpınar ve Kilyos kumları için $a_{b}-\tan \psi_{p}$ ilişkisinin değişim hızı benzerdir. Fakat tüm kumlar için benzer olan durum, artan genleşme açısının göçme yüzeyi eğriliğini arttırmasıdır. Bu beklenen bir sonuçtur; zira genleşme hareketinin vektörü kayma yüzeyine dik olmaktadır ve kayma yüzeyinin takip ettiği yön genleşme vektörü ile kayma yüzeyi hareketi vektörünün bileşkesidir. Daha yüksek genleşme açısı daha yüksek eğriliğe sahip kayma yüzeyleri oluşturmaktadır.

Şekil 14'te PGHÖ yöntemi ile tespit edilen gerçek göçme yüzeyi geometrileri Altunbaş v.d. (2017), Rankine (1856) ve Vardoulakis (1980) bağıntıları kullanarak tahmin edilen göçme yüzeyi geometrileri ile karşılaştırılmıştır. Sonuçlar incelendiğinde, aktif göçme yüzeylerini tanımlamak için parabolik fonksiyonun uygun olduğu anlaşılmaktadır. Bunun sonucu olarak Altunbaş v.d. (2017) tarafından önerilen fonksiyonun ölçüm ile tespit edilen göçme yüzeylerine en yakın tahmini yaptığı rahatlıkla görülmektedir. Bunun sebebi Rankine (1856) ve Vardoulakis (1980) tarafından önerilmiş doğrusal fonksiyonların göçme yüzeyinin eğriliğini yakalayamamasıdır. Ancak, Altunbaş v.d. (2017) bağıntısının uygulamalarda kullanılabilmesi için $\mathrm{a}_{\mathrm{b}}$ ve $\alpha$ değerlerinin $\psi_{p}$ ile değişiminin zemin özelliklerinin fonksiyonu olarak tanımlanması gereklidir. Bu sebeple farklı tane dağılım ve şekline sahip zeminler üzerinde deneyler yapılması gerekli olmaktadır.

\section{SONUÇLAR}

Bu çalışma kapsamında önce dayanma yapısı ardında oluşan aktif göçme yüzeylerini kontrol eden zemin özellikleri araştırılmıştır. Bu amaçla fiziksel model deneyleri yapılmış ve sonuçlar görüntü işleme teknikleri kullanılarak yorumlanmıştır. Bunu izleyerek, model çalışmalarında kullanılan üç farklı zemin tipinin mekanik özellikleri deneyler ile elde edilmiştir. Elde edilen mekanik özellikler literatürde kabul gören gerilme-genleşme ilişskilerinde kullanılarak, her model deneydeki zeminin genleşme ve sürtünme açıları hesaplanmıştır. Böylece zeminlerin tane şekli, boyutu ve tane dağılımı gibi fiziksel özellikleri ile içsel sürtünme ve genleşme açıları gibi mekanik özelliklerinin aktif göçme yüzey geometrilerine etkileri araştırılmıştır. Bu çalışma sonucunda aktif göçme yüzeyi geometrisini tanımlamak için en uygun fonksiyon tipinin parabolik olduğu anlaşılmıştır. Göçme yüzeyinin parabolik fonksiyon ile tanımlanması için iki geometrik özelliğe ihtiyaç duyulmaktadır. Bunlar, göçme yüzeyinin başlangıç eğimi $(\alpha)$ ve göçme yüzeyinin yer seviyesine ulaştığı noktanın duvara yatay mesafesinin doğrusal göçme yüzeyinin yatay mesafesine oranıdır $\left(a_{b}\right)$. Deneyler sonucunda $\alpha$ değerinin genleşme açısındaki artış ile arttığı tespit edilmiştir. Ayrıca, kum tanelerinin ortalama küreselliği değerindeki azalış $\alpha$ değerinde artışa sebep olmaktadır. Buna ek olarak daha düzgün tane boyutu dağılımına sahip kumların daha yüksek $\alpha$ açısına sahip aktif göçme yüzeyleri oluşturdukları gözlenmiştir. Öte yandan $a_{b}$ büyüklüğü genleşme açısındaki artış ile azalmaktadır. Dolayısıyla yüksek genleşme açısının daha eğri göçme yüzey geometrisine yol açtığı anlaşılmaktadır. 
Kohezyonsuz Zeminlerin Tane Dağılım ve Şekil Özelliklerinin Aktif Göçme ...

\section{Semboller}

$\mathrm{a}_{\mathrm{b}} \quad: \mathrm{B}_{\mathrm{f}} / \mathrm{X}$ oranı

$\mathrm{A}_{\Psi} \quad$ : hacimsel genleşme açısına Dilatasyon indeksinin katkısını belirten katsayı

B : göçme yüzeyindeki herhangi bir noktanın duvar üstünden olan yatay mesafesi

$\mathrm{B}_{\mathrm{f}} \quad$ : duvar ile göçme yüzeyi arasındaki yatay mesafenin yer seviyesindeki değeri

C : Eşitlik 2'de uzunluğa bağlı bir katsayı

$\mathrm{C}_{\mathrm{c}} \quad$ : derecelenme katsayıs 1

$\mathrm{C}_{\mathrm{u}} \quad$ : Üniformluk katsayısı

d : Duvar ötelenmesi

$\mathrm{D}_{50} \quad$ : Ortalama tane çap1

e $\quad$ maks maksimum boşluk oranı

$\mathrm{e}_{\min } \quad$ : minimum boşluk oranı

g : : yer çekimi ivmesi

$\mathrm{G}_{\mathrm{s}} \quad$ : özgül ağırlık

$\mathrm{H}_{\mathrm{w}} \quad$ : fiziksel model deneyindeki istinat duvarı yüksekliği

$\mathrm{I}_{\mathrm{D}} \quad$ : göreceli sıkılık

$\mathrm{I}_{\mathrm{R}} \quad$ : genleşme indeksi

$\mathrm{K}_{\mathrm{a}} \quad$ : aktif göçme durumundaki yanal toprak basıncı katsayısı

$\mathrm{K}_{0} \quad$ : sükunetteki yanal toprak basıncı katsayısı

$\mathrm{kPa} \quad$ : kilopascal

LE : yanal uzama gerilme izi

$\mathrm{mm}$ : milimetre

q : deviatorik gerilme

Q : : deneye bağlı Bolton (1986) formül parametresi

$\mathrm{p}_{\mathrm{a}} \quad$ : atmosferik basınç

$\mathrm{p}_{\mathrm{f}}^{\prime} \quad$ : göçme durumundaki efektif ortalama gerilme

$\mathrm{p}_{\mathrm{o}}^{\prime} \quad$ : sükunetteki efektif ortalama gerilme

$\mathrm{r} \quad$ : sürtünme açısına genleşme açısının etkisini tanımlayan katsayı

R : : deneye bağlı Bolton (1986) formül parametresi

$\mathrm{R}_{\text {ort }} \quad$ : ortalama yuvarlakl1k

$\mathrm{r}_{\mathrm{ps}} \quad$ : düzlem gerilme koşullarında sürtünmeye genleşme etkisini tanımlayan katsayı 


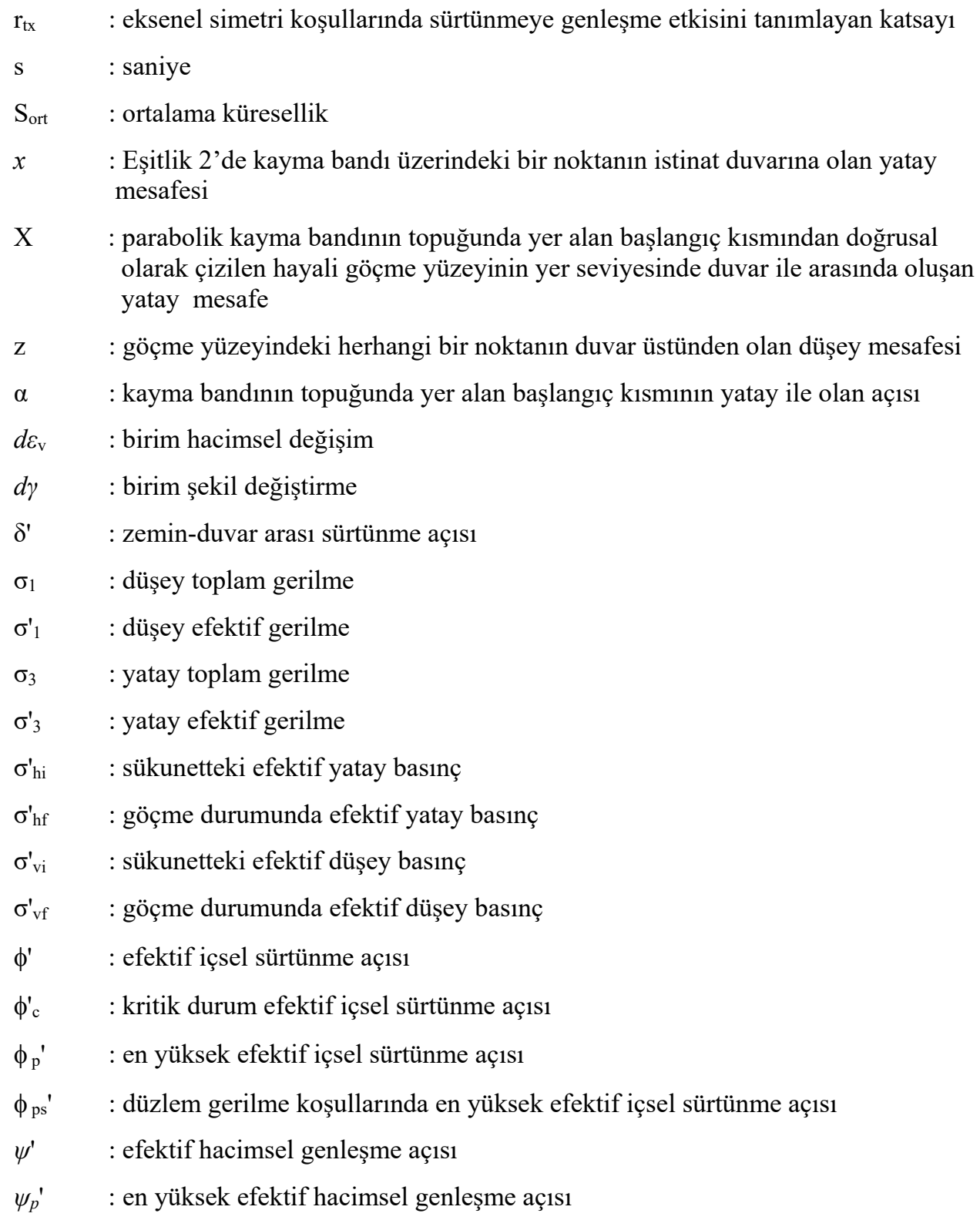

\section{Teşekkür}

Yazarlar bu çalışmayı 114M329 no'lu proje kapsamında destekleyen TÜBİTAK'a teşekkür ederler. 


\section{Kaynaklar}

[1] Rankine, W.M.J., On Stability of Loose Earth. Philisophic Transactions of Royal Society, London, Part I, 9-27, 1857.

[2] Coulomb, C.A., Essai sur une application des regles de maximis et minimis quelques problemes de statique, relatits a l'architecture. Memoires de Mathematique de l'Academie Royale de Science, 7, Paris, 1776.

[3] Tsagareli, Z.V., Experimental Investigation of the pressure of a loose medium on retaining walls with a vertical back face and horizontal backfill surface, Soil Mechanics and Foundation Engineering, Volume 2, Issue 4, pp 197-200, 1965.

[4] Vardoulakis, I., Shear band inclination and shear modulus of sand in biaxial tests. Int. J. Numer. Anal. Met. Geomech., 4(2), 103-119, 1980.

[5] Bang, S., Active Earth Pressure Behind Retaining Walls. Journal of Geotechnical Engineering, Vol.111, No.3, 407-412, 1985.

[6] Fang, Y.S., Ishibashi, I., Static Earth Pressures with Various Wall Movements. Journal of Geotechnical Engineering, Vol.112, Issue 3, 1986.

[7] Paik, K.H., Salgado, R., Estimation of active earth pressure against rigid retaining walls considering arching effects. Geotechnique 53, No. 7, 643-653, 2003.

[8] Goel, S., Patra, N.R., Effect of arching on active earth pressure for rigid retaining walls considering translation mode. Int. J. Geomech., 8(2), 123-133, 2008.

[9] Ertuğrul, N., Effect of soil arching on lateral soil pressures acting upon rigid retaining walls. Yüksek Lisans Tezi, ODTÜ, 2013.

[10] Rao, P.P., Chen, Q., Nimbalkar, S.S., Chiaro, G., Determination of Active Earth Pressure on Rigid Retaining Wall Considering Arching Effect in Cohesive Backfill Soil. International Journal of Geomechanics, 2015.

[11] Kowalska, M., Numerical study of the Influence of the Dilatancy Angle on Bearing Capacity and Rotation of a Gravity Retaining Wall. 15.Danube European Conference on Geotechnical Engineering, Paper No. 186, 2014.

[12] Oda, M., Initial fabrics and their relations to mechanical properties of granular material, Japanese Society of Soil Mechanics and Foundation Engineering. Vol.12, No.1, 1972.

[13] Holubec, I., Appolonia, E.D., Effect of particle shape on the engineering properties of granular soils. ASTM, 304-318, 1973.

[14] Frossard, E., Effect of sand grain shape on interparticle friction. Geotechnique 29, No. 3, 341-350, 1979.

[15] Jensen, R.P., Edil, T.B., Bosscher, P.J., Plesha, M.E., Kahla, N.B., Effect of particle shape on interface behavior of DEM-simulated granular materials. The International Journal of Geomechanics, Volume 1, Number 1, 1-9, 2001. 
[16] Cho, G.C., Dodds, J., Santamarina, J.C., Particle Shape Effects on Packing Density, Stiffness and Strength: Natural and Crushed Sands. J. Geotech. Geoenviron. Eng., 132(5), 591-602, 2006.

[17] Amirpour, S., Karray, M., Hussien, M.N., Chekired, M., Influence of particle size and gradation on the stress-dilatancy of granular material during CD test. International Journal of Geomechanics, 17(9): 04017077, 2017.

[18] Bolton, M.D., Strength and dilatancy of sands. Geotechnique 36(1), 65-78, 1986.

[19] Reynolds, O., On the Dilatancy of Media Composed of Rigid Particles in Contact. Philosophical Magazine and Journal of Science, Fifth series, 1886.

[20] Taylor, D.W., Fundamentals of Soil Mechanics, New York. Wiley and Sons, 1948.

[21] Rowe, P.W., The Stress-Dilatancy Relation for Static Equilibrium of an Assembly of Particles in Contact. Proceedings of the Royal Society, London, 500-527, 1962.

[22] Rowe, P.W., The Relation Between the Shear Strength of Sands in Triaxial Compression, Plane Strain and Direct Shear. Geotechnique 19, No.1, 75-86, 1969.

[23] De Josselin de Jong, G., Rowe's Stress-Dilatancy Relation Based on Friction. Geotechnique 26, No.3, 527-534, 1976.

[24] Bishop, A.W., Shear Strength Parameters for Undisturbed and Remolded Soil specimens. Proceedings of the Roscoe Memorial Symposium, Cambridge University, Cambridge, MA, USA, pp.3-58, 1971.

[25] Chakraborty, T. and Salgado, R., Dilatancy and shear strength of sand at low confining pressures. J. Geotech. Geoenviron. Eng., 136(3), 527-532, 2010.

[26] Altunbas, A., Soltanbeigi, B., Cinicioglu, O., Determination of Active Failure Surface Geometry for Cohesionless Backfills. Geomechanics and Engineering, Vol.12, No.6, 983-1001, 2017.

[27] Peters, J.F., Lade, P.V., Shear Band Formation in Triaxial and Plane Strain Tests. Advanced Triaxial Testing of Soil and Rock, ASTM STP977, Philadelphia, 604-627, 1988.

[28] Schanz, T., Vermeer, P.A., Angles of Friction and Dilatancy of Sand. Geotechnique 46, No.1, 145-151, 1996.

[29] Hanna, A., Determination of Plane-Strain Shear Strength of Sand from the results of Triaxial Tests. Canadian Geotechnical Journal, 36,6 pg. 1231, 2001.

[30] Moore, S.D., McCabe, G.P., Introduction ot the practice of statistics. $4^{\text {th }}$ edition, W.H. Freeman and Company, New York, 2003.

[31] Krumbein, W.C., Sloss, L.L., Stratigraphy and Sedimentation. Freeman, San Francisco, 1963.

[32] Vaid, Y. P., Sasitharan, S., The strength and dilatancy of sand. Canadian Geotechnical Journal, 29(3), 522-526, 1992. 
[33] Niedostatkiewicz, M., Lesniewska, D., Tejchman, J., Experimental Analysis of Shear Zone Patterns in Sand During Earth Pressure Problems using Particle Image Velocimetry. Strain, Vol 47, 218-231, 2011.

[34] Lesniewska, D., Muir Wood, D., Photoelastic and Photographic Study of a Granular Material. Geotechnique, Vol 61, No 7 605-611, 2011.

[35] Pietrzak, M., Lesniewska, D., Failure evaluation in granular material retained by rigid wall in active mode. Studia Geotechnica et Mechanica, Vol. 34 No. 4, 2012.

[36] Tehrani, S., Arshad, M.I., Prezzi, M., Salgado, R., Visualization of active mode of failure behind flexible walls under pure rotation using digital image correlation. GeoCongress Technical Papers, GSP 234, ASCE, 2014.

[37] White, D.J., Take, W.A., Bolton, M.D., Soil Deformation Measurement using particle image velocimetry (PIV) and photogrammetry. Geotechnique 53, No. 7, 619-631, 2003. 